RYSZARD NOWICKI

Katedra Informacji Naukowej i Bibliologii

Uniwersytet Kazimierza Wielkiego w Bydgoszczy

\title{
POLSKIE ZBIORNICE KSIĘGOZBIORÓW ZABEZPIECZONYCH W LATACH 1947-1955'
}

W powojennej historii niezwykle ważne zadania miały do spełnienia zbiornice księgozbiorów zabezpieczonych. Jednak ich rola i znaczenie w odbudowie bibliotek oraz polskiego bibliotekarstwa pozostają mało znane. Problematyka związana $\mathrm{z}$ funkcjonowaniem tych instytucji nie znalazła należytego odzwierciedlenia w literaturze. Poza nielicznymi artykułami ${ }^{2}$, nie cieszyła się jak dotąd zainteresowaniem badaczy. Trzeba przyznać, że praca $\mathrm{w}$ zbiornicach w zasadzie traktowana była marginesowo. Prawdopodobnie $\mathrm{z}$ tego też powodu, poza nielicznymi wyjątkami, jej kierownicy nie pozostawili informacji w opublikowanej formie. Natomiast dotarcie do materiałów archiwalnych nie jest zadaniem łatwym. W niniejszym artykule przedstawione zostaną: geneza, funkcjonowanie oraz rezultaty działalności polskich zbiornic księgozbiorów zabezpieczonych w latach 1947-1955. Autor wykorzystał przede wszystkim dokumenty źródłowe, zwłaszcza sprawozda-

\footnotetext{
${ }^{1}$ Projekt został sfinansowany ze środków Narodowego Centrum Nauki przyznanych na podstawie decyzji numer DEC-2011/03/B/HS2/05446

2 A. Dróżdż, Działalność katowickiej Zbiornicy Księgozbiorów Zabezpieczonych na Górnym Śląsku w latach 1947-1955, „Śląski Kwartalnik Historyczny Sobótka” 2012, nr 2, s. 81-100; A. Jazdon, Bolesław Świderski jako kierownik Zbiornicy Księgozbiorów Zabezpieczonych w Poznaniu - przyczynek do poznańskiego okresu działalności [w:] Bibliotekarstwo według Bolesława Świderskiego - Myśl, praktyka, dydaktyka. Księga Pamiątkowa, pod red. S. Kurek-Kokocińskiej, Łódzkie Towarzystwo Naukowe, Łódź 2009, s. 35-55; R. Nowicki, Rezultaty działalności Zbiornicy Księgozbiorów Zabezpieczonych w Szczecinie w latach 1947-1950, „Roczniki Biblioteczne”, 2007, R. LI, s. 169-188; tenże, Aleksander Birkenmajer jako wizytator Zbiornicy Księgozbiorów Zabezpieczonych we Wrocławiu, „Biblioteka”, 2013, Nr 17 (26), s. 139-151.
} 
nia, przechowywane w Archiwum Akt Nowych w Warszawie, Archiwum Biblioteki Uniwersyteckiej w Poznaniu, Archiwum Uniwersytetu Wrocławskiego. Dokumenty sporządzone przez kierowników zbiornic: Karola Badeckiego (Kraków), Stefana Burhardta (Toruń), Helenę Kalewską (Gdańsk), Marię Quirini (Szczecin), Franciszka Szymiczka (Katowice), Bolesława Świderskiego (Poznań) i Edwarda Zubika (Wrocław) dają wgląd w niezwykle skomplikowaną i bogatą działalność zbiornic.

Należy wspomnieć, iż zbiornice książek mają kilkuwiekową tradycję. Pierwsze z nich powstały w okresie Wielkiej Rewolucji Francuskiej. W wyniku przemian ustrojowych doszło do utworzenia na terenie tego kraju składnic, w których gromadzono dzieła, również te pochodzące ze zbiorów kościelnych. Powstanie zbiornic pozostaje więc w ścisłym związku z wydarzeniami przełomowymi $\mathrm{w}$ danym państwie. Tak też było w przypadku Polski. Niniejsze rozważania dotyczą zbiornic księgozbiorów, utworzonych 1 lutego 1947 roku, decyzją Ministerstwa Oświaty ${ }^{3}$. Formalnie działały one do 1949 roku. Tylko jedna z nich, Zbiornica Księgozbiorów Zabezpieczonych w Katowicach, funkcjonowała do 31 grudnia 1955 roku.

W kraju wyniszczonym przez okupantów dotkliwie odczuwano brak słowa pisanego. Władze państwowe, w niezwykle trudnych powojennych warunkach przystąpiły do ratowania książek, odbudowy bibliotek, organizowania sieci bibliotecznej. Mieszkańców cieszyła każda wiadomość o otwarciu biblioteki, czytelni czy powiększeniu księgozbioru. Przykładowo we Wrocławiu, 8 czerwca 1946 roku, nastąpiło uroczyste przekazanie zbiorów Biblioteki Miejskiej Uniwersytetowi Wrocławskiemu. Jan Muszkowski, w liście skierowanym z tej okazji do dyrektora Biblioteki Uniwersyteckiej Antoniego Knota, prowadzącego powojenną ochronę zbiorów bibliotecznych na terenie Dolnego Śląska, podkreślił znaczenie tego aktu, tak ważnego „zarówno dla akcji naszej na ziemiach zachodnich, jak dla dziejów naszego bibliotekarstwa"4.

Na terenie kraju, zwłaszcza na ziemiach przyłączonych w wyniku postanowień Wielkiej Trójki, pozostawały liczne księgozbiory, głównie poniemieckiej proweniencji, wymagające natychmiastowych działań ochronnych. W wyniku zmian terytorialnych i społeczno-politycznych zabezpieczeniu podlegały księgozbiory tzw. opuszczone i porzucone. W myśl Ustawy

\footnotetext{
${ }^{3}$ Komunikat Naczelnej Dyrekcji Bibliotek Ministerstwa Oświaty o utworzeniu zbiornic-segregatorni, A. Knot, Polskie prawo biblioteczne, Książnica-Atlas, Wrocław-Warszawa 1947, s. 117.

${ }^{4}$ Archiwum Uniwersytetu Wrocławskiego (dalej cyt. AUWr), Przekazanie Biblioteki Miejskiej Uniwersytetowi, sygn. BU 82, k. 30 - J. Muszkowski do Dyrekcji Biblioteki Uniwersyteckiej we Wrocławiu, Łódź 21 czerwca 1946 r.
} 
z 6 maja 1945 roku o majątkach opuszczonych i porzuconych ${ }^{5}$ do pierwszej grupy zaliczano te, które $\mathrm{w}$ związku $\mathrm{z}$ wojną rozpoczętą 1 września 1939 roku nie znajdowały się w posiadaniu właścicieli; a do drugiej zbiory, które były własnością lub w posiadaniu państwa niemieckiego, obywateli niemieckich bądź osób zbiegłych do nieprzyjaciela. Liczne dzieła narażone były na zniszczenie. Przemarsze i postoje wojsk oraz niekorzystne zjawisko, określone mianem powojennego szabru, powodowały nieodwracalne straty. Rękopisy, inkunabuły, stare druki oraz wydania XIX i XX-wieczne zaczęto więc gromadzić w specjalnych budynkach oraz pomieszczeniach, zwanych magazynami książek, składnicami lub też zbiornicami. Ratowaniem zbiorów zajęły się różne instytucje, jednak największe osiągnięcia odnotowało Ministerstwo Oświaty, w wyniku prowadzonych centralnie prac, nakreślonych przez Józefa Grycza ${ }^{6}$.

Uściślenia wymaga, dla celów niniejszego artykułu, termin zbiornica, który występuje w źródłach rękopiśmiennych oraz jest wzmiankowany w literaturze w różnych kontekstach ${ }^{7}$ W wyniku decyzji Resortu Oświaty PKWN, z 29 listopada $1944 \mathrm{roku}^{8}$, na władze szkolne I i II instancji (tj. inspektoraty i kuratoria szkolne) nałożony został obowiązek ochrony zbiorów bibliotecznych. Książki miały być przechowywane w specjalnych zabezpieczonych pomieszczeniach. Zgromadzone w większej ilości zaczęły tworzyć lokalne oraz regionalne magazyny, zwane np. zbiornicami powiatowymi czy kuratoryjnymi. Rozpoczęty przez władze szkolne proces ochrony materiałów bibliotecznych prowadzili okręgowi kierownicy biblioteczni, ustanowieni na mocy decyzji Ministra Oświaty Stanisława Skrzeszewskiego z 15 lutego $1945 \mathrm{roku}^{9}$. Zostali nimi:

- dla województw krakowskiego i kieleckiego - dyrektor Biblioteki Jagiellońskiej w Krakowie,

- dla województwa śląskiego - dyrektor Biblioteki Publicznej w Katowicach,

${ }^{5}$ Ustawa z dnia 6 maja 1945 r. o majątkach opuszczonych i porzuconych, Dz. U. R. P. 1945 nr 17 poz. 97.

${ }^{6}$ Zob.: R. Nowicki, Rola Józefa Grycza w powojennej ochronie zbiorów bibliotecznych, „Z Badań nad Książką i Księgozbiorami Historycznymi” 2011, t. 5, s. 89-108.

${ }^{7}$ Np. po II wojnie światowej powstawały zbiornice odpadków, do których trafiały w znacznych ilościach książki.

${ }^{8}$ Okólnik Resortu Oświaty w sprawie zabezpieczenia bibliotek i zbiorów bibliotecznych, Nr Bbl. IV - W - 2195/44, Dziennik Urzędowy Resortu Oświaty 1944 nr 1/4 poz. 32.

9 Archiwum Biblioteki Uniwersyteckiej w Poznaniu, Referat zabezpieczania i segregacji zbiorów. Zarządzenia, instrukcje i upoważnienia 1944-1946, sygn. 535, k. 13 - Minister Oświaty do Ministerstwa Rolnictwa i Reform Rolnych w Warszawie w sprawie zabezpieczenia bibliotek, Kraków 15 II 1945 r. (odpis). 
- dla województwa łódzkiego - dyrektor Biblioteki Miejskiej w Łodzi,

- dla województw poznańskiego i pomorskiego - dyrektor Biblioteki Uniwersyteckiej w Poznaniu.

Kierowali oni dalszą ochroną zbiorów bibliotecznych i przejmowali wcześniej zabezpieczone dzieła w terenie, które następnie trafiły do zbiornic powstałych w 1947 roku. Warto zwrócić uwagę, iż w materiałach źródłowych występują sprawozdania zbiornic od 1947 roku, ale także obejmujące całokształt działań od chwili rozpoczęcia powojennej ochrony zbiorów bibliotecznych, aż do jej zakończenia na danym terenie. Przykładowo Bolesław Świderski, kierownik poznańskiej Zbiornicy, który przesłał Ministerstwu Oświaty dokument zatytułowany Sprawozdanie z działalności Zbiornicy Księgozbiorów Zabezpieczonych w Poznaniu. Lata 1945-195010. Sytuacja ta wynikała $\mathrm{z}$ faktu kontynuacji przez zbiornicę powojennej ochrony zbiorów bibliotecznych, rozpoczętej tuż po ustąpieniu okupanta hitlerowskiego. Krajowe zbiornice m.in. przejmowały księgozbiory zabezpieczone pierwotnie przez inne instytucje, a zwłaszcza przez władze szkolne, i umieszczały je w swoich magazynach, by móc następnie poddać zwieziony materiał segregacji oraz repartycji.

Jaka jest geneza polskich zbiornic? Powstanie instytucji pozostaje w ścisłym związku z prowadzoną ochroną zbiorów bibliotecznych, która została zapoczątkowana na wschodnich terenach kraju w 1944 roku. Władze uznały, że pierwszy etap ratowania zbiorów, polegający głównie na zabezpieczeniu materiałów bibliotecznych, dobiegł końca w 1946 roku. Wobec tego, na początku 1947 roku, po utworzeniu na terenie kraju zbiornic-sortowni, przystapiono do drugiego etapu, związanego przede wszystkim z segregacją i repartycją zwiezionych dzieł. Wyjątkową inicjatywę w tym zakresie wykazał Stanisław Sierotwiński, którego pomysły i doświadczenie zyskały akceptację Ministerstwa Oświaty. Należy w tym miejscu wspomnieć o wydarzeniach wcześniejszych. W Pabianicach od 24 do 27 października 1945 roku trwała konferencja okręgowych wizytatorów bibliotek, z udziałem przedstawicieli bibliotek uniwersyteckich prowadzących ochronę zbiorów oraz Ministerstwa Oświaty ${ }^{11}$. W celu skoordynowania i scentralizowania działań

${ }^{10}$ Archiwum Akt Nowych (dalej cyt. AAN), Ministerstwo Oświaty. Naczelna Dyrekcja Bibliotek. Wydział Bibliotek Naukowych. Zbiornica Księgozbiorów Zabezpieczonych w Poznaniu. Sprawozdania z działalności za lata 1945-1950, sygn. 6953, k. 2-14 - B. Świderski, Sprawozdanie z działalności Zbiornicy Ksiegozbiorów Zabezpieczonych w Poznaniu. Lata 1945-1950, Poznań 23 III 1950 r.

${ }^{11}$ Zob.: Aktualne zagadnienia bibliotekarskie. Pierwsza powojenna konferencja okręgowych wizytatorów bibliotek $w$ dniach 24-27 października 1945 r. w Pabianicach, Nakładem Ministerstwa Oświaty, Warszawa 1946. 
związanych z ratowaniem księgozbiorów w Polsce, podjęto wówczas decyzję o powołaniu Delegatury Ministerstwa Oświaty w Krakowie. Na jej czele stanął Stanisław Sierotwiński ${ }^{12}$, któremu podlegał obszar kraju podzielony na sześć okręgów:

I Krakowski,

II Wrocławski,

III Szczeciński,

IV Gdański,

V Olsztyński,

VI Lubuski.

Stosunkowo nieliczny zespół, liczący około 30 osób, przystąpił do zabezpieczania dzieł. Przez trzynaście miesięcy, od 1 grudnia 1945 roku do 31 grudnia 1946 roku, Stanisław Sierotwiński poddał ochronie 5462704 tomy, z czego do Krakowa przewieziono 1793704 tomy. W trakcie prac mierzył się z licznymi trudnościami związanymi z transportowaniem dzieł. Spotkał się m.in. z zarzutami masowego wywozu księgozbiorów do Krakowa. Zmęczony zaistniałą sytuacją, zaproponował nowe rozwiązanie związane $\mathrm{z}$ utworzeniem na terenie Polski kilku zbiornic-sortowni. W połowie listopada 1946 roku przedstawił projekt zorganizowania ich w Gdańsku, Poznaniu, Szczecinie, Krakowie oraz Katowicach (względnie w Bytomiu). Według Stanisława Sierotwińskiego takie rozmieszczenie placówek miało ukrócić wszelkie spekulacje o zamiarach scentralizowania i nierównomiernego rozprowadzania książek poniemieckich na terenie kraju. Pomysł zyskał aprobatę Ministerstwa Oświaty, które poleciło krakowskiemu delegatowi prowadzenie rozmów w terenie celem zorganizowania sortowni.

Ministerstwo Oświaty 1 lutego 1947 roku utworzyło na terenie kraju siedem zbiornic-sortowni: w Gdańsku, Katowicach, Krakowie, Poznaniu, Szczecinie, Toruniu ${ }^{13}$ i Wrocławiu. Do podstawowych zadań i kompetencji instytucji należało:

- odszukanie w terenie i przewiezienie materiałów bibliotecznych do zbiornic,

${ }_{12}$ Zob.: R. Nowicki, Działalność Stanisława Sierotwińskiego w latach 1945-1946 jako delegata Ministerstwa Oświaty do zabezpieczania ksiegozbiorów opuszczonych i porzuconych na Ziemiach Zachodnich, „Roczniki Biblioteczne” 2006, R. L, s. 13-44.

${ }_{13}$ Zbiornica w Toruniu nie została wymieniona w Komunikacie Naczelnej Dyrekcji Bibliotek Ministerstwa Oświaty o utworzeniu zbiornic-segregatorni. Placówka powstała również 1 lutego 1947 r. - AAN, Ministerstwo Oświaty. Naczelna Dyrekcja Bibliotek. Wydz.[iał] Bibliotek Naukowych. Zbiornica Księgozbiorów przy Bibliotece Uniwersyteckiej w Toruniu. Sprawozdanie z działalności za lata 1947-49, sygn. 6 956, k. 1 - S. Burhardt do Naczelnej Dyrekcji Bibliotek w Ministerstwie Oświaty, Toruń 3 kwietnia 1950 roku. 
- zmagazynowanie przetransportowanych zbiorów,

- segregacja (według instrukcji Ministerstwa Oświaty z dnia 25 stycznia 1946 roku w sprawie postępowania $\mathrm{z}$ księgozbiorami zabezpieczonymi, opracowanej przez Józefa Grycza); przedstawianie potrzeb dotyczących posegregowanych materiałów,

- przekazywanie zbiorów na podstawie otrzymanych upoważnień z Ministerstwa Oświaty innym instytucjom.

Lokalizacja zbiornic nie była przypadkowa. Wynikała z podjętych wcześniej czynności związanych $\mathrm{z}$ ochroną zbiorów bibliotecznych. W terenie bowiem działali przedstawiciele Ministerstwa Oświaty. W Krakowie w lutym 1945 r. powstał Zarząd Główny Bibliotek województw krakowskiego, kieleckiego i rzeszowskiego. Był to organ wykonawczy Biblioteki Jagiellońskiej aktywnie uczestniczący w powojennym ratowaniu księgozbiorów. Jego kierownikiem został Stanisław Sierotwiński, który stanął później na czele krakowskiej Delegatury Ministerstwa Oświaty. Atutem dawnej stolicy Polski był fakt, że miasto uniknęło zniszczeń podczas wojny, w przeciwieństwie do Warszawy, i dysponowało pomieszczeniami, zwłaszcza na Wawelu, mogącymi pomieścić liczne zbiory zwożone z całego kraju. W Katowicach czynności prowadził dyrektor Biblioteki Śląskiej Michał Rybicki. Podlegał mu obszar Górnego Śląska. We Wrocławiu pracami kierował Antoni Knot. Teren Dolnego Śląska obfitował w księgozbiory poniemieckiej proweniencji, w tym przetransportowane przez Niemców podczas wojny z Berlina, celem ich ochrony przed spodziewanym bombardowaniem Trzeciej Rzeszy. W Poznaniu czynności podlegały dyrektorowi Biblioteki Uniwersyteckiej Aleksandrowi Birkenmajerowi, który wykazał aktywność na terenie Wielkopolski oraz częściowo Dolnego Śląska i Pomorza Zachodniego ${ }^{14}$. W Gdańsku zabezpieczaniem zbiorów zajął się dyrektor Biblioteki Miejskiej Marian Pelczar, a w Toruniu Stefan Burhardt, zwożąc książki z Pomorza Zachodniego, Pomorza Wschodniego oraz dawnych Prus Wschodnich.

Zbiornice były instytucjami samodzielnymi, podlegającymi bezpośrednio Ministerstwu Oświaty. Jedynie katowicka Zbiornica w latach pięćdziesiątych wchodziła w skład struktury organizacyjnej Ministerstwa Kultury i Sztuki. Kierownicy dysponowali możliwością zatrudniania w nich osób oraz decydowali o wydatkowaniu przyznanych im środków finansowych. Magazyny zbiornic-sortowni mieściły się w różnych budynkach, a także

${ }^{14}$ R. Nowicki, Działalność Aleksandra Birkenmajera na rzecz powojennej ochrony zbiorów bibliotecznych w Polsce. Ziemie zachodniej i pótnocnej Polski w latach 1945-1947, Uniwersytet im. Adama Mickiewicza w Poznaniu, Prace Biblioteki Uniwersyteckiej Nr 27, Poznań 2006. 
$\mathrm{w}$ innych miastach. Pracownicy mieli w zasadzie znośne warunki do segregacji przetransportowanych materiałów bibliotecznych. W pierwszym okresie nie starczało bowiem czasu na liczenie dzieł. Należało je przede wszystkim zabezpieczyć przed zniszczeniem. Pracom towarzyszył stale duży pośpiech. Stąd też w źródłach z tego okresu występują często jedynie szacunkowe dane. Książki przeliczano na kilogramy, tony, wagony kolejowe, wozy konne, platformy samochodowe, skrzynie, worki, wiązki, paki, pakiety, pliki, platony ${ }^{15}$, a nawet metry sześcienne. Dopiero powstanie zbiornic-sortowni stworzyło możliwość dokładnego przeliczenia zwiezionego materiału. Jednak nie zawsze było to możliwe. $\mathrm{Z}$ powodu braku miejsca, nierzadko także regałów oraz panującej ciasnoty, dzieła przesortowane mieszały się z czekającymi na segregację. Należy także pamiętać, iż nadal zwożono księgozbiory z terenu. Nie występowały one jednak w takiej obfitości, jak w pierwszym okresie, tj. przed utworzeniem zbiornic-sortowni.

Funkcjonowanie zbiornic wyznacza ważne cezury związane z powojenną ochroną zbiorów bibliotecznych. Jak długo bowiem ona trwała? Prace zostały zapoczątkowane, jak wspomniano, już w 1944 roku. Formalnie zbiornice, za wyjątkiem jednej, zostały rozwiązane 31 grudnia 1949 roku. Faktycznie zakończyły działalność na początku lat pięćdziesiątych. Do niektórych $\mathrm{z}$ nich nadal transportowano książki z terenu. Najdłużej, do 31 grudnia 1955 roku, działała Zbiornica Księgozbiorów Zabezpieczonych w Katowicach. W latach pięćdziesiątych przejmowała ona księgozbiory kilku likwidowanych zbiornic. Do Katowic zwożono książki z tak odległych miast, jak Gdańsk czy Szczecin. Należy zatem przyjąć, że powojenna ochrona została zakończona 31 grudnia 1955 roku, wraz z likwidacją ostatniej Zbiornicy Księgozbiorów Zabezpieczonych w Katowicach. 1 stycznia 1956 roku stała się ona Działem, a w 1970 roku Oddziałem Biblioteki Narodowej (zlikwidowanym w 1999 roku). Powróćmy jednak do ram chronologicznych. Wyznaczają je lata 1944-1955. Można w nich wyróżnić trzy okresy:

- pierwszy, związany z rozpoczęciem na skrawku ziem polskich powojennej ochrony zbiorów bibliotecznych w 1944 roku, i zabezpieczeniem księgozbiorów w terenie, trwał do końca 1946 roku,

- drugi rozpoczął się na początku 1947 roku, wraz z utworzeniem zbiornic-sortowni, a zakończył ich formalną likwidacją (oprócz jednej) z końcem 1949 roku,

- trzeci, obejmujący lata 1950-1955, związany jest z pracą katowickiej Zbiornicy Księgozbiorów Zabezpieczonych.

\footnotetext{
15 Typ skrzyni.
} 
Jak przedstawiało się funkcjonowanie zbiornic i jakie były rezultaty ich działalności? By móc odpowiedzieć na te pytania, należy przyjrzeć się pracy poszczególnych zbiornic, tj. w Gdańsku, Katowicach, Krakowie, Poznaniu, Szczecinie, Toruniu oraz Wrocławiu.

Gdańską Zbiornicą Księgozbiorów Zabezpieczonych, zorganizowaną 1 marca 1947 roku $^{16}$, kierował początkowo Marian Pelczar, a od połowy następnego roku Helena Kalewska. Swoim zasięgiem obejmowała teren województwa gdańskiego. Zwożono do niej książki m.in.: z Gdańska, Gdyni, Kartuz, Kwidzyna, Lęborka, Malborka, Oliwy, Sopotu, Starogardu Gdańskiego, Sztumu, Tczewa, Wejherowa. Zbiornica mieściła się w budynku Biblioteki Miejskiej oraz częściowo w niewielkim pomieszczeniu w suterenie Szkoły Powszechnej nr $1 \mathrm{w}$ Gdańsku. Do tego ostatniego miejsca przewożono część przesortowanych tomów. Książki składano w piwnicach i na strychu Biblioteki Miejskiej. Ze względu na trudności lokalowe w 1948 roku postanowiono wykorzystać sale lekcyjne, podczas letnich wakacji szkolnych, do składowania przywożonych dzieł. Prace postępowały dość wolno z powodu braku wykwalifikowanych bibliotekarzy. Trudności segregacyjne sprawily m.in. pozycje pisane językiem Braillea. Wystąpiły także poważne problemy $\mathrm{z}$ transportem. Na terenie województwa gdańskiego brakowało pojazdów, a koszty wynajęcia samochodu początkowo przekraczały budżet kierownika Zbiornicy. Prace rozpoczęto z półtoramiesięcznym opóźnieniem, po otrzymaniu pierwszych subwencji na ten cel. Również w późniejszym czasie były one wstrzymywane z powodu przerw w przekazywaniu kredytów z Ministerstwa Oświaty oraz ze względu na brak miejsc do ulokowania zwożonych książek. Zgromadzone dzieła w budynku szkolnym na II piętrze, wskutek zbyt dużego obciążenia podłogi, spowodowały pękanie sufitu. Woluminy układano zatem $\mathrm{w}$ innym pomieszczeniu na podłodze. W Bibliotece Miejskiej dokonywano translokacji stosów książek, które ucierpiały z powodu wilgoci w bardziej suche miejsca. Sortowanie odbywało się w zimnej i słabo oświetlonej piwnicy. Częste przemieszczanie zbiorów nie sprzyjało rytmicznej pracy.

Transportowane dzieła znajdowały się w różnym stanie technicznym. Te zwiezione z Inspektoratu Szkolnego w Starogardzie Gdańskim były mocno uszkodzone, wiele $\mathrm{z}$ nich nie miało okładek oraz kart tytułowych. Najbardziej zniszczone pozostawały książki przywiezione $\mathrm{z}$ Kartuz. Wiele z nich już wówczas miało wartość makulatury.

16 AAN, Ministerstwo Oświaty. Naczelna Dyrekcja Bibliotek. Wydz.[iał] Bibliotek Naukowych. Zbiornica Księgozbiorów Zabezpieczonych $w$ Gdańsku. Sprawozdania miesięczne z działalności za lata 1947-49, sygn. 6 945, k. 1 - M. Pelczar, Sprawozdanie z działalności Zbiornicy Księgozbiorów Zabezpieczonych w Gdańsku za okres od dnia 1 marca do dnia 31 lipca 1947 r. 
Na mocy decyzji Naczelnej Dyrekcji Bibliotek Ministerstwa Oświaty dzieła przekazywano m.in.: Akademii Lekarskiej w Gdańsku, Bibliotece Miejskiej w Gdańsku, Politechnice Gdańskiej, Wyższej Szkole Pedagogicznej w Gdańsku, Uniwersytetowi Łódzkiemu, Seminarium Duchownemu w Pelplinie, Instytutowi Bałtyckiemu w Sopocie, Uniwersytetowi Mikołaja Kopernika w Toruniu, Akademii Wychowania Fizycznego w Warszawie, Akademii Sztabu Generalnego w Warszawie, Ministerstwu Przemysłu Lekkiego w Warszawie, Uniwersytetowi Warszawskiemu. Część materiałów pozostawała do dyspozycji Katolickiego Uniwersytetu Lubelskiego w Lublinie.

Gdańska Zbiornica zakończyła działalność 15 kwietnia 1950 roku $^{17}$, ale jeszcze tego samego roku transportowano do niej dzieła z terenu. Do Zbiornicy, według obliczeń kierowniczki Heleny Kalewskiej, zwieziono ogółem 217278 książek, z których przesegregowano $199387^{18}$. Przekazano natomiast różnym instytucjom 43317 dzieł. Stan zbiorów po zlikwidowaniu Zbiornicy w kwietniu 1950 roku wynosił 173933 książki.

Siedziba krakowskiej Zbiornicy Księgozbiorów Zabezpieczonych znajdowała się w Bibliotece Jagiellońskiej. Magazyny Zbiornicy zorganizowano w tej placówce, na Wawelu oraz w kilku punktach miasta (w Akademii Sztuk Pięknych, Gimnazjum Nowodworskiego, Gimnazjum św. Jacka, Instytucie Geograficznym Uniwersytetu Jagiellońskiego, baraku przy ul. Miodowej). Ze sprawozdania sporządzonego w marcu 1948 roku wynika, że czasopisma poniemieckie z 5 wagonów przechowywane na Wawelu przewieziono do gmachu Biblioteki Jagiellońskiej ${ }^{19}$. W magazynach wawelskich pozostawały liczne skrzynie, do których można było dotrzeć dopiero po wywiezieniu czasopism $^{20}$. Ekspertyza dokonana przez kierownika Zbiornicy, wspólnie z przedstawicielem Archiwum Państwowego w Krakowie wykazała, że w 18 skrzyniach znajdowały się archiwalia miejskie ze Zgorzelca. Natomiast 77 skrzyń zawierało materiały wyłącznie biblioteczne, pochodzące z Biblioteki Miejskiej w Zgorzelcu oraz innych księgozbiorów publicznych i prywatnych z tego miasta oraz terenu Śląska.

17 AAN, Ministerstwo Oświaty. Naczelna Dyrekcja Bibliotek. Wydz.[iat] Bibliotek Naukowych. Zbiornica Księgozbiorów Zabezpieczonych w Gdańsku. Sprawozdania miesięczne $z$ działalności za 1950 r., sygn. 6 946, k. 6 - H. Kalewska, Sprawozdanie z działalności Zbiornicy Księgozbiorów Zabezpieczonych w Gdańsku za miesiąc kwiecień 1950 roku.

18 Tamże.

19 AAN, Ministerstwo Oświaty. Naczelna Dyrekcja Bibliotek. Wydz.[iał] Bibliotek Naukowych. Zbiornica Księgozbiorów Zabezpieczonych w Krakowie. Sprawozdania z działalności 1948-1949, sygn. 6 952, k. 1 - K. Badecki, VI Sprawozdanie Kierownictwa księgozbiorów zabezpieczonych w Krakowie, Kraków 25 marca 1948 r.

20 Tamże. 
W lipcu 1948 roku personel zwiózł ostatnią część książek poniemieckich z Wawelu ${ }^{21}$. Do Biblioteki Jagiellońskiej przetransportowano również z Cieszyna, Katowic i Bytomia resztki książek pochodzących z księgozbiorów Tarnowskich z Suchej i Tyszkiewiczów z Czerwonego Dworu. Materiał ten został posegregowany i w układach chronologicznym oraz alfabetycznym włączony do księgozbiorów. Uporządkowano alfabetycznie zrekonstruowane katalogi kartkowe zbiorów: Tarnowskich z Dzikowa, Lubomirskich z Przeworska, Tarnowskich z Suchej, Tyszkiewiczów z Czerwonego Dworu oraz Potockich z Krzeszowic.

W magazynie przy ul. Miodowej, po zwiezieniu do Biblioteki Jagiellońskiej licznych rozsortowanych książek poniemieckich, oczekiwały na wywóz grupy dzieł, które Ministerstwo Oświaty zamierzało przekazać Spółdzielni Wydawniczej „Czytelnik”. Były wśród nich zasoby: literatury pięknej, dla młodzieży oraz popularnonaukowej. Pozostawiono również wszelkie wydawnictwa dotyczące religii protestanckiej i propagandy niemieckiej, z przeznaczeniem ich na makulaturę. W lipcu 1948 roku rozpoczęto translokację siedmiu wagonów czasopism pochodzących z Biblioteki Państwowej w Berlinie (Staatsbibliothek Berlin). Zbiornica dysponowała dwoma samochodami ciężarowymi marki Chevrolet. Wysokie koszty utrzymania, częste awarie oraz kosztowne remonty nie sprzyjały właściwemu wykorzystaniu pojazdów.

W sierpniu i we wrześniu 1948 roku rozsortowano zespoły biblioteczne Urzędu Generalnego Gubernatora, Starosty Miasta Krakowa, Oddziału Nauki i Oświaty Generalnego Gubernatorstwa ${ }^{22}$. Z magazynu przy ul. Miodowej przetransportowano połowę pozostających w nim czasopism, które pochodzily z Staatsbibliothek Berlin.

W III kwartale 1948 roku w krakowskiej sortowni zatrudnionych było siedem osób ${ }^{23}$. Wszyscy kontraktowi pracownicy z dniem 1 sierpnia 1948 roku otrzymali kilkumiesięczne wypowiedzenia z pracy. Sytuacja ta wynikała z planowanego zakończenia działalności Zbiornicy.

${ }^{21}$ AAN, Ministerstwo Oświaty. Naczelna Dyrekcja Bibliotek. Wydz.[iał] Bibliotek Naukowych. Zbiornica Księgozbiorów Zabezpieczonych w Krakowie. Sprawozdania z działalności 1948-1949, sygn. 6 952, k. 4 - K. Badecki, IX Sprawozdanie Kierownictwa księgozbiorów zabezpieczonych w Krakowie, Kraków 25 sierpnia 1948 roku.

${ }^{22}$ AAN, Ministerstwo Oświaty. Naczelna Dyrekcja Bibliotek. Wydz.[iat] Bibliotek Naukowych. Zbiornica Księgozbiorów Zabezpieczonych w Krakowie. Sprawozdania z działalności 1948-1949, sygn. 6 952, k. 7 - K. Badecki, X Sprawozdanie Kierownictwa księgozbiorów zabezpieczonych w Krakowie, Kraków 2 października 1948 roku.

${ }^{23}$ AAN, Ministerstwo Oświaty. Naczelna Dyrekcja Bibliotek. Wydz.[iat] Bibliotek Naukowych. Zbiornica Księgozbiorów Zabezpieczonych w Krakowie. Sprawozdania z działalności 1948-1949, sygn. 6 952, k. 9 - K. Badecki do Ministerstwa Oświaty Naczelnej Dyrekcji Bibliotek w Warszawie, Kraków 11 października 1948 roku. 
W październiku i listopadzie 1948 roku personel sortowni zatrudniano głównie przy przewożeniu (pakowaniu i wyładowywaniu według grup) posegregowanych książek poniemieckich, zabieranych z baraku przy ul. Miodowej ${ }^{24}$. W ten sposób dobiegała końca likwidacja ostatniego magazynu. Od połowy grudnia 1948 roku czynności prowadzono już wyłącznie w Bibliotece Jagiellońskiej. W budynku tej instytucji zmagazynowano w całości wszystkie zabezpieczone czasopisma pochodzące ze Staatsbibliothek Berlin oraz materiały biblioteczne ze zlikwidowanych magazynów w mieście.

31 grudnia 1948 roku zwolniono pracowników kontraktowych sortowni. Pozostali jedynie kierownik Karol Badecki i sekretarka Urszula Stasiak. W lutym 1949 roku krakowska Zbiornica Księgozbiorów Zabezpieczonych była w stanie likwidacji ${ }^{25}$. Pod koniec miesiąca 500000 dzieł poniemieckich było złożone w stosach z powodu braku miejsca i odpowiednich regałów w piwnicznych pomieszczeniach Biblioteki Jagiellońskiej. Przeważały czasopisma, literatura piękna, pozycje z zakresu przemysłu, handlu, komunikacji, nauk społeczno-prawnych, publikacje religijno-teologiczne oraz popularno-naukowe. Nie brakowało także starych druków i rękopisów.

Zabezpieczone materiały Zbiornica wydawała innym instytucjom, m.in.: Archiwum Państwowemu w Krakowie, Bibliotece Jagiellońskiej, Bibliotece Narodowej w Warszawie, Ministerstwu Kultury i Sztuki w Warszawie, Archiwum Państwowemu we Wrocławiu. Zgodnie z zaleceniem Naczelnej Dyrekcji Bibliotek Ministerstwa Oświaty z 8 marca 1948 roku przekazała Wojskowemu Instytutowi Geograficznemu w Warszawie cały zasób map poniemieckich. Ilość zrulowanych dokumentów wypełniła osiem wagonów kolejowych, a ich ciężar obliczono na sto ton ${ }^{26}$. Materiały kartograficzne zostały zabrane w dniach 15-18 marca 1948 roku.

Instytucje miały możliwość dokonania wyboru dzieł zabezpieczonych. Delegat Ministerstwa Spraw Zagranicznych, Jerzy Dudziński, 1 lutego 1949 roku przejął z magazynów krakowskiej Zbiornicy ogółem 443 skrzynie

${ }^{24}$ AAN, Ministerstwo Oświaty. Naczelna Dyrekcja Bibliotek. Wydz.[iał] Bibliotek Naukowych. Zbiornica Księgozbiorów Zabezpieczonych w Krakowie. Sprawozdania z działalności 1948-1949, sygn. 6 952, k. 12 - K. Badecki, XI Sprawozdanie Kierownictwa księgozbiorów zabezpieczonych w Krakowie, Kraków 9 grudnia 1948 roku.

25 AAN, Ministerstwo Oświaty. Naczelna Dyrekcja Bibliotek. Wydz.[iat] Bibliotek Naukowych. Zbiornica Księgozbiorów Zabezpieczonych w Krakowie. Sprawozdania z działalności 1948-1949, sygn. 6 952, k. 15 - K. Badecki, XII Sprawozdanie Kierownictwa księgozbiorów zabezpieczonych w Krakowie, Kraków 24 lutego 1949 roku.

26 AAN, Ministerstwo Oświaty. Naczelna Dyrekcja Bibliotek. Wydz.[iał] Bibliotek Naukowych. Zbiornica Księgozbiorów Zabezpieczonych w Krakowie. Sprawozdania z działalności 1948-1949, sygn. 6 952, k. 3 - K. Badecki, VI Sprawozdanie Kierownictwa księgozbiorów zabezpieczonych w Krakowie, Kraków 25 marca 1948 roku. 
z materiałami archiwalno-bibliotecznymi, pochodzącymi z Belgii i Holandii $^{27}$. Zasoby pięciu historycznych polskich księgozbiorów podworskich, tj. Tarnowskich z Dzikowa, Tarnowskich z Suchej, Tyszkiewiczów z Czerwonego Dworu, Lubomirskich z Przeworska i Potockich z Krzeszowic liczyły około 60000 tomów. Na mocy decyzji Ministerstwa Oświaty księgozbiór Tarnowskich z Suchej rozdzielono pomiędzy Bibliotekę Zakładu Narodowego im. Ossolińskich we Wrocławiu i Bibliotekę Miejską w Gdańsku. Księgozbiór Lubomirskich z Przeworska przeznaczono w całości Ossolineum we Wrocławiu. Część dzieł pozostawała w Bibliotece Jagiellońskiej bez przydziału. Materiały te oczekiwały na zabranie przez instytucje z całego kraju. Krakowska Zbiornica najszybciej zakończyła pracę. Sytuacja ta wynikała z faktu dysponowania odpowiednimi magazynami do przechowywania książek oraz wykwalifikowanym personelem.

Zbiornica Księgozbiorów w Toruniu nie została wymieniona w dokumencie Ministerstwa Oświaty o utworzeniu zbiornic-sortowni, chociaż powstała również 1 lutego 1947 roku. Jako jedyna instytucja nie miała, przez cały okres funkcjonowania, znaku własnościowego w postaci pieczęci ${ }^{28}$. Posługiwano się nazwą: Zbiornica Księgozbiorów przy Bibliotece Uniwersyteckiej w Toruniu. Kierownikiem, od czasu jej powstania do 18 lipca 1949 roku, był pierwszy dyrektor Biblioteki Uniwersyteckiej, Stefan Burhardt ${ }^{29}$. Następnie pracami kierował Ludwik Kolankowski. Zbiornica kontynuowała prace, które zostały rozpoczęte $\mathrm{w}$ ramach działalności Biblioteki. Ściśle współpracowała z Biblioteką Uniwersytecką, z którą posiadała wspólny lokal i kierownictwo. Specyfika tej placówki polegała na tym, że Biblioteka Uniwersytecka miała prawo pierwszeństwa przydziału książek ze Zbiornicy. Sytuacja ta wynikała $\mathrm{z}$ faktu utworzenia w 1945 r. Uniwersytetu i Biblioteki. W momencie powstania instytucja nie miała żadnych książek. Należało zatem stworzyć podwaliny własnego księgozbioru. Taka możliwość istniała wówczas jedynie poprzez pozyskanie księgozbiorów zabezpieczonych. Prawo pierwszeństwa w otrzymywaniu książek w praktyce oznaczało niemalże

27 AAN, Ministerstwo Oświaty. Naczelna Dyrekcja Bibliotek. Wydz.[iał] Bibliotek Naukowych. Zbiornica Księgozbiorów Zabezpieczonych w Krakowie. Sprawozdania z działalności 1948-1949, sygn. 6 952, k. 16 - K. Badecki, XII Sprawozdanie Kierownictwa księgozbiorów zabezpieczonych w Krakowie, Kraków 24 lutego 1949 roku.

${ }^{28} \mathrm{Na}$ dokumentach związanych z działalnością Zbiornicy widnieją znaki Biblioteki Uniwersyteckiej w Toruniu.

${ }^{29}$ AAN, Ministerstwo Oświaty. Naczelna Dyrekcja Bibliotek. Wydz.[iat] Bibliotek Naukowych. Zbiornica Księgozbiorów przy Bibliotece Uniwersyteckiej w Toruniu. Sprawozdanie z działalności za lata 1947-49, sygn. 6 956, k. 1 - S. Burhardt do Naczelnej Dyrekcji Bibliotek w Ministerstwie Oświaty, Toruń 3 kwietnia 1950 roku. 
monopol Biblioteki na książki pochodzące ze Zbiornicy ${ }^{30}$. Woluminy wydawano także innymi bibliotekom, ale stosunkowo rzadko, gdyż niewiele placówek zgłaszało się po nie. Przyjmowano zatem każdą książkę do tworzonego od podstaw księgozbioru uniwersyteckiego. Dopiero po pewnym czasie utworzono wspólny, dla Zbiornicy i Biblioteki, Dział Dubletów.

Trudności wynikały z częstej translokacji zwiezionego materiału bibliotecznego. Zbiornica niemalże do końca funkcjonowania nie dysponowała własnymi regałami. Książki układano więc w pryzmy. Prace wykonywało do kilkunastu pracowników. Główne czynności skierowane były na wyszukiwanie pozycji do zbiorów specjalnych (rękopisów, inkunabułów, starych druków, czasopism, map i atlasów, nut). Tomy dzielono według dziedzin wiedzy i przystępowano do szybkiego ich katalogowania. Następnie każdą z tych grup dzielono na kilka podgrup. Dokonywano także podziału ze względu na format, język, wyłączano stare druki i polonica. Wyodrębniono książki z lat 1801-1850 celem ich późniejszego opracowania i ustawienia w osobnym magazynie.

Transporty książek, przekraczające kilka tysięcy woluminów szacowane były „na oko” ${ }^{31}$. Dzieła te ładowano do skrzyń. Natomiast zwożone w mniejszych ilościach segregowano na bieżąco. Starano się zachować proweniencję zbiorów. Jednak wykonywanie prac w ogromnym pośpiechu, zmiana lokali Zbiornicy i brak regałów uniemożliwiały sporządzenie dokładnej statystyki oraz oddzielne ich przechowywanie. Wyłączone natomiast książki stanowiły kilka odrębnych grup: propaganda hitlerowska, podręczniki szkolne, książki popularne, literatura dziecięca, nakłady.

Od 1 września 1945 roku do 18 lipca 1949 roku zwieziono do Torunia z 55 miejscowości (m.in.: Białogardu, Braniewa, Brodnicy, Bydgoszczy, Chełmna, Człuchowa, Chojnic, Elbląga, Ełku, Fromborka, Gdańska, Grudziądza, Jamna, Koszalina, Lęborka, Morąga, Nawry, Olsztyna, Panzina, Ponarzyna, Poznania, Sławna, Słupska, Szczytna, Tolkmicka, Warcina, Wieldządza) łącznie 597409 woluminów ${ }^{32}$. Z tego Zbiornica rozsegregowała ponad połowę, tj. 307747 woluminów.

${ }^{30}$ AAN, Ministerstwo Oświaty. Naczelna Dyrekcja Bibliotek. Wydz.[iał] Bibliotek Naukowych. Zbiornica Księgozbiorów przy Bibliotece Uniwersyteckiej $w$ Toruniu. Sprawozdanie z działalności za lata 1947-49, sygn. 6 956, k. 2 - S. Burhardt, Sprawozdanie rzeczowe Zbiornicy Księgozbiorów przy Bibliotece Uniwersyteckiej w Toruniu za okres od 1.II.1947 - 18.VII.1949 r., czyli od powstania Zbiornicy do przekazania Biblioteki i Zbiornicy dyrektorowi prof. d-rowi Ludwikowi Kolankowskiemu, Toruń 3 kwietnia 1950 roku.

31 Tamże.

${ }^{32}$ Tamże, k. 4. 
Zgromadzone dzieła przekazywano także innym instytucjom, m.in.: Archiwum Państwowemu w Szczecinie, Archiwum Państwowemu w Gdańsku, Bibliotece Miejskiej w Gdańsku, Archiwum Miejskiemu w Toruniu, Uniwersytetowi w Warszawie, Towarzystwu Archeologicznemu w Poznaniu, Bibliotece Miejskiej w Inowrocławiu, Gimnazjum Redemptorystów w Toruniu, Bibliotece Narodowej w Warszawie, Ministerstwu Administracji Publicznej w Warszawie, Książnicy Miejskiej w Toruniu.

Główne magazyny Zbiornicy Księgozbiorów Zabezpieczonych we Wrocławiu znajdowały się w stolicy Dolnego Śląska. Kierownik Edward Zubik zorganizował także dodatkowe punkty, w tym w Chojnowie. Z przesłanego przez Zbiornicę sprawozdania, za sierpień i wrzesień 1948 roku wynikało, że sześć osób w ciągu 1900 godzin przesegregowało i skompletowało 48424 tomy czasopism ${ }^{33}$. Średnio na godzinę, na jednego zatrudnionego, przypadało ponad 25 tomów. W październiku tego roku przy sortowaniu książek zabezpieczonych przez Bibliotekę Uniwersytecką pracowało siedmiu pracowników ${ }^{34}$. W czasie 691 godzin przesortowali oni 13290 tomów ${ }^{35}$.

Na podstawie protokołów zdawczo-odbiorczych stwierdzono, że w latach 1947-1949 do Zbiornicy zwieziono 877958 tomów (w tym 77342 tomy bez protokołów zdawczo-odbiorczych) ${ }^{36}$. Wszystkie księgozbiory zostały przesegregowane. 190342 tomy wydano innym instytucjom (z tego około 100000 tomów w 1949 roku). Stan wrocławskiej Zbiornicy 31 grudnia 1949 roku wynosił 687616 tomów $^{37}$. Z tego 44350 tomów stanowiły zbiory specjalne, 222975 piśmiennictwo naukowe, 30515 regionalia, 15021 publicystyka i propaganda niemiecka oraz 374755 inne

${ }_{33}$ AAN, Ministerstwo Oświaty. Naczelna Dyrekcja Bibliotek. Wydz.[iat] Bibliotek Naukowych. Zbiornica Księgozbiorów Zabezpieczonych we Wrocławiu. Sprawozdania miesięczne z działalności za 1948 rok., sygn. 6 958, k. 3 - E. Zubik, Sprawozdanie z segregacji zbiorów zabezp.[ieczonych] przez Bibliotekę Uniwersytecka, Wrocław 12 listopada 1948 roku.

${ }^{34}$ AAN, Ministerstwo Oświaty. Naczelna Dyrekcja Bibliotek. Wydz.[iat] Bibliotek Naukowych. Zbiornica Księgozbiorów Zabezpieczonych we Wrocławiu. Sprawozdania miesięczne z działalności za 1948 rok, sygn. 6 958, k. 1 - E. Zubik do Ministerstwa Oświaty w Warszawie, Wrocław 17 grudnia 1948 roku.

35 AAN, Ministerstwo Oświaty. Naczelna Dyrekcja Bibliotek. Wydz.[iał] Bibliotek Naukowych. Zbiornica Księgozbiorów Zabezpieczonych we Wrocławiu. Sprawozdania miesięczne z działalności za 1948 rok, sygn. 6 958, k. 2 - Sprawozdanie za miesiac październik, Wrocław 16 listopada 1948 roku.

${ }^{36}$ AAN, Ministerstwo Oświaty. Naczelna Dyrekcja Bibliotek. Wydz.[iat] Bibliotek Naukowych. Zbiornica Księgozbiorów Zabezpieczonych we Wrocławiu. Sprawozdania miesięczne z działalności za 1950 rok, sygn. 6 959, k. 2 - Stan Zbiornicy na dzień 30 XII 1949 r.

37 Tamże.

W sprawozdaniu zatytułowanym Stan Zbiornicy na dzień 30 XII 1949 r., podano stan na 31 tego miesiąca - uwaga RN. 
grupy. W wyniku dalszego zwożenia książek z terenu liczba ogólna wzrosła pod koniec lutego 1950 roku do 707187 tomów $^{38}$, a we wrześniu tego samego roku do 767987 tomów ${ }^{39}$. Książki ze Zbiornicy przekazano do m.in.: Muzeum Etnograficznego w Łodzi, Seminarium Historycznego Uniwersytetu Poznańskiego, Instytutu Orientalistycznego Uniwersytetu Warszawskiego, Ministerstwa Kultury i Sztuki w Warszawie, Studium Planowania Przestrzennego przy Uniwersytecie Wrocławskim, Zakładu Polityki Społecznej Uniwersytetu Łódzkiego, Wyższej Szkoły Ekonomicznej w Łodzi, Biblioteki Uniwersyteckiej we Wrocławiu, Zakładu Psychologii Ogólnej Uniwersytetu Wrocławskiego, Biblioteki Głównej Politechniki Łódzkiej, Wojewódzkiej Rady Łowieckiej w Opolu, Wojewódzkiego Zakładu Higieny Weterynaryjnej we Wrocławiu, Zakładu Polityki Społecznej Uniwersytetu Łódzkiego, Muzeum Wojska Polskiego w Warszawie, Biblioteki Publicznej m.st. Warszawy, Instytutu Historycznego, Zakładu Historii Sztuki, Zakładu Estetyki, Zakładu Muzykologii i Zakładu Geografii Uniwersytetu Łódzkiego, Głównego Urzędu Statystycznego w Warszawie, Archiwum Państwowego we Wrocławiu, Głównego Instytutu Pracy w Warszawie, Szkoły Głównej Gospodarstwa Wiejskiego w Warszawie, Politechniki Wrocławskiej, Uniwersytetu Jagiellońskiego w Krakowie, Wyższej Szkoły Muzycznej w Krakowie, Muzeum Wojska Polskiego we Wrocławiu, Uniwersytetu Mikołaja Kopernika w Toruniu, Akademii Górniczo-Hutniczej w Krakowie, Instytutu Kształcenia Kadr Naukowych przy KC PZPR w Warszawie, Akademii Medycznej, Zakładu Konserwacji Zabytków w Krakowie, Urzędu Patentowego w Warszawie, Głównego Instytutu Pracy w Chorzowie, Zakładu i Seminarium Historii Literatury Zachodnio-Słowiańskiej Uniwersytetu Poznańskiego, Zakładu Archeologii Klasycznej Uniwersytetu Wrocławskiego, Centralnego Śląskiego Instytutu Medycyny Pracy w Rokitnicy Bytomskiej, Ministerstwa Gospodarki Komunalnej w Warszawie.

Stan Zbiornicy 31 grudnia 1950 roku wynosił 760629 tomów ${ }^{40}$. W ciągu tego roku zwieziono 144102 książki, a wydano 71089 pozycji. Wysorto-

${ }^{38}$ AAN, Ministerstwo Oświaty. Naczelna Dyrekcja Bibliotek. Wydz.[iał] Bibliotek Naukowych. Zbiornica Księgozbiorów Zabezpieczonych we Wrocławiu. Sprawozdania miesięczne z działalności za 1950 rok, sygn. 6 959, k. 4 - E. Zubik, Sprawozdanie rzeczowe za miesiac luty 1950 roku.

39 AAN, Ministerstwo Oświaty. Naczelna Dyrekcja Bibliotek. Wydz.[iał] Bibliotek Naukowych. Zbiornica Księgozbiorów Zabezpieczonych we Wrocławiu. Sprawozdania miesięczne z działalności za 1950 rok, sygn. 6 959, k. 26 - E. Zubik, Sprawozdanie rzeczowe za miesiąc maj 1950 roku.

${ }^{40}$ AAN, Ministerstwo Oświaty. Naczelna Dyrekcja Bibliotek. Wydz.[iał] Bibliotek Naukowych. Zbiornica Księgozbiorów Zabezpieczonych we Wrocławiu. Sprawozdania miesięczne z działalności za 1950 rok., sygn. 6 959, k. 30 - E. Zubik, Roczne sprawozdanie rzeczowe za rok 1950. 
wanych 8577 kg dzieł (6900 tomów) przekazano do Zbiornicy Odpadków Użytkowych.

W Poznaniu zabezpieczanie zbiorów bibliotecznych prowadził Aleksander Birkenmajer. Kierował pracami związanymi z ochroną księgozbiorów do sierpnia 1947 roku. Był pierwszym kierownikiem poznańskiej Zbiornicy Księgozbiorów Zabezpieczonych. Kolejnym, od 1 września 1947 roku, został Bolesław Świderski, który prowadził tę instytucję aż do jej likwidacji, 31 grudnia $1949 \mathrm{roku}^{41}$. Obszar działania Aleksandra Birkenmajera początkowo obejmował Wielkopolskę oraz częściowo Dolny Śląsk i Pomorze Zachodnie. Po utworzeniu zbiornic w Szczecinie i Wrocławiu czynności zostały ograniczone do terenu województwa poznańskiego. Ogółem w latach 1945-1949 zabezpieczono i zwieziono 1223851 tomów, z tego w latach 1947-1949 304551 tomów ${ }^{42}$. W latach 1945-1947 przesortowano, według proweniencji, 750000 tomów. Wówczas prace wykonywano przede wszystkim w kościołach św. Michała, św. Stanisława i św. Małgorzaty (dawne składnice poniemieckie książek). W 1948 roku przesegregowano 216970 tomów ${ }^{43}$, a rok później 158090 tomów ${ }^{44}$. Z chwilą likwidacji Zbiornicy do segregacji pozostało w magazynach około 100000 tomów. Działalność Zbiornicy polegała głównie na zabezpieczaniu i zwożeniu zbiorów, segregacji oraz repartycji. Ta ostatnia czynność obejmowała zwrot książek prawowitym właścicielom (instytucjom i osobom prywatnym) oraz dotyczyła przekazywania książek placówkom naukowym. Ogółem zwrócono i przekazano księgozbiory 280 instytucjom oraz kilkuset osobom prywatnym. W latach 1945-1949 dokonano repartycji 945880 tomów, z tego w latach 1947-1949 336721 tomów ${ }^{45}$. Repartycja dotyczyła w pierwszej kolejności instytucji na terenie Poznania, a następnie w innych miastach. Książki zostały przekazane lub zwrócone: Bibliotece Uniwersyteckiej w Poznaniu - około 250000 tomów, Bibliotece Poznańskiego Towarzystwa Przyjaciół Nauk - około 100000 tomów, Bibliotece Publicznej m. Poznania - około 100000 tomów. Ponadto dzieła przekazano: Gminie Żydowskiej, Bibliotece Archidiecezjalnej, Bibliotece Akademii Handlowej, kilkudziesięciu biblio-

${ }^{41}$ AAN, Ministerstwo Oświaty. Naczelna Dyrekcja Bibliotek. Wydz.[iat] Bibliotek Naukowych. Zbiornica Księgozbiorów Zabezpieczonych w Poznaniu. Sprawozdanie z działalności za lata 194550., sygn. 6 953, k. 2 - B. Świderski, Sprawozdanie z działalności Zbiornicy Księgozbiorów Zabezpieczonych w Poznaniu. Lata 1945-1950.

42 Tamże, k. 8.

43 Tamże.

${ }_{44}$ Tamże, k. 9.

45 Tamże, k. 8. 
tekom zakładowym Uniwersytetu Poznańskiego, Bibliotece Pedagogicznej Kuratorium Okręgu Szkolnego Poznańskiego, bibliotekom gimnazjalnym oraz urzędom i instytucjom publicznym ${ }^{46}$.

Z ośrodków poza Poznaniem repartycja objęła m.in.: Bibliotekę Kapitulną w Gnieźnie, Bibliotekę Seminarium Duchownego we Włocławku, Bibliotekę Seminarium Historii Literatury w Toruniu, Wyższą Szkołę Pedagogiczną w Łodzi, zakłady Uniwersytetu Łódzkiego, Państwowy Instytut Książki w Łodzi, Muzeum Narodowe w Krakowie, Akademię Sztabu Generalnego w Warszawie, Centralną Bibliotekę Wojskową w Warszawie, Bibliotekę Narodową, Wydział Teologii Ewangelickiej Uniwersytetu Warszawskiego, Zakład Orientalistyki Uniwersytetu Warszawskiego, Ministerstwo Kultury i Sztuki, Ministerstwo Komunikacji, Polskie Towarzystwo Filologiczne w Warszawie, Główny Instytut Mechaniki w Warszawie, Główny Urząd Statystyczny, Muzeum Ziemi Bytomskiej w Chorzowie, Bibliotekę Wyższego Studium Nauk Społecznych w Katowicach, zakłady Uniwersytetu Marii Curie-Skłodowskiej w Lublinie ${ }^{47}$.

Po likwidacji Zbiornicy zbiory przeszły pod administrację Biblioteki Uniwersyteckiej w Poznaniu. Pod koniec lutego 1950 roku liczyły one około 286000 tomów $^{48}$.

Zbiornica Księgozbiorów Zabezpieczonych w Szczecinie dysponowała sortowniami w: Szczecinie, Koszalinie, Słupsku, Stargardzie i Wałczu ${ }^{49}$. Pracami od maja 1947 roku kierowała Maria Quirini. Zlokalizowanie magazynów w pięciu miastach miało na celu przyspieszenie zwózki książek, szybkie dostarczenie ich do segregacji i umożliwienie Ministerstwu Oświaty przeprowadzenia repartycji dla uniwersytetów, bibliotek naukowych i instytucji społecznych. Czynności były prowadzone przez kilku pracowników, jednak tylko osoby sortujące w Szczecinie miały stałe zatrudnienie.

W 1947 roku zwieziono łącznie około 200000 woluminów. Prace podjęto m.in. w szczecińskiej Zbiornicy Odpadków. Po przejrzeniu 40 ton książek wysortowano 16 ton dzieł różnej treści naukowej. Część pozycji zwiezionych do Zbiornicy znajdowała się $\mathrm{w}$ fatalnym stanie, np. przetransportowane z Dyszna. Przez dwa lata leżały one w skrzyniach i stertach na polu.

46 Tamże.

47 Tamże, k. 10.

48 Tamże, k. 12.

49 AAN, Ministerstwo Oświaty. Naczelna Dyrekcja Bibliotek. Wydz.[iał] Bibliotek Naukowych. Zbiornica Księgozbiorów Zabezpieczonych w Szczecinie. Sprawozdanie z całokształtu akcji zabezpieczania księgozbiorów poniemieckich w latach 1947-50, sygn. 6 955, k. 1 - M. Quirini do Ministerstwa Oświaty, Szczecin 14 maja 1950 roku. 
Ogółem w 1948 roku zwieziono 250000 woluminów, a rok później około 220000 woluminów. Do 30 marca 1950 roku Zbiornica zabrała prawie wszystkie książki z terenu, o których miała informacje. Tego roku dokonała przydziałów dzieł dla 38 uniwersytetów i zakładów naukowych.

Kierownikiem Zbiornicy Księgozbiorów Zabezpieczonych w Katowicach, na mocy pisma Ministerstwa Oświaty z dnia 17 lutego 1947 roku $^{50}$, został Franciszek Szymiczek, prowadzący działalność na terenie województwa śląsko-dąbrowskiego. Do końca 1949 roku katowickiej Zbiornicy podlegał obszar jednego regionu, a od 1950 roku, po zlikwidowaniu zbiornic, teren całego kraju.

Zbiornica miała dwa oddziały: w Katowicach (Śląska Biblioteka Publiczna) i Bytomiu. Główny magazyn znajdował się w Bytomiu, gdzie prowadzono większość prac. Przed zwiezieniem tomów Franciszek Szymiczek dokonywał selekcji pozycji na miejscu ich przechowywania, by oddzielić dzieła wartościowe, które następnie transportował do Bytomia. W ten sposób szukał oszczędności w kosztach transportu oraz racjonalnego wykorzystania pomieszczeń. Wszystkich zabezpieczonych materiałów bibliotecznych lokale nie były bowiem $\mathrm{w}$ stanie pomieścić. $\mathrm{W}$ terenie występowały one w ogromnych ilościach. Celem usprawnienia pracy uruchomił kilkanaście powiatowych magazynów książek w: Gliwicach, Zabrzu, Bytomiu, Oleśnie, Kluczborku, Nysie, Niemodlinie, Strzelcach, Opolu, Miechowicach, Katowicach (Biblioteka Miejska), Koźlu, Prudniku, Głubczycach, Raciborzu oraz Rybniku. Pracownicy natrafiali przede wszystkim na zbiory proweniencji poniemieckiej, a także instytucji i osób prywatnych z Belgii, Francji, Holandii, Łotwy, Związku Radzieckiego, Jugosławii, Rumunii czy Austrii. Występowały także judaica.

Katowicka Zbiornica w latach pięćdziesiątych likwidowała inne krajowe zbiornice, w których pozostawały licznie zgromadzone dzieła. Do jesieni 1950 roku całkowicie zlikwidowana została szczecińska Zbiornica oraz w 50 procentach gdańska ${ }^{51}$. Zabrano $\mathrm{z}$ nich stosunkowo niewielką ilość tomów. Najwięcej przetransportowano pozycji z Wrocławia. Z likwidowanej w la-

\footnotetext{
50 AAN, Ministerstwo Oświaty. Naczelna Dyrekcja Bibliotek. Wydział Bibliotek Naukowych. Zbiornica Księgozbiorów Zabezpieczonych $w$ Katowicach. Sprawozdania miesięczne $z$ działalności za 1947 r., sygn. 6 947, k. 1 - F. Szymiczek, Sprawozdanie rzeczowe za okres od 1 marca do 26 kwietnia $1947 r$.

51 AAN, Ministerstwo Oświaty. Naczelna Dyrekcja Bibliotek. Wydział Bibliotek Naukowych. Zbiornica Księgozbiorów Zabezpieczonych w Katowicach. Sprawozdania miesięczne $z$ działalności za 1950 r., sygn. 6 950, k. 61 - F. Szymiczek, Sprawozdanie z działalności rzeczowej Zbiornicy za miesiac październik 1950 r., Katowice 13 listopada $1950 \mathrm{r}$.
} 
tach 1951-1952 wrocławskiej Zbiornicy skierowano do Bytomia 500000 książek $^{52}$. Z Biblioteki Uniwersyteckiej we Wrocławiu przekazano 210000 woluminów, a kolejnych 90000 woluminów przygotowano do wysyłki. $\mathrm{Z}$ tego, po wstępnej selekcji, oddano na makulaturę 300000 woluminów, a z Biblioteki Uniwersyteckiej 140000 woluminów.

W sumie katowicka Zbiornica, w latach 1947-1955, zabezpieczyła i przejęła 1349006 woluminów książek i roczników czasopism (1947 rok - 77 207; 1948 rok - 154 786; 1949 rok - 101 724; 1950 rok - 91 227; 1951 rok - 694 727; 1952 rok - 104 272; 1953 rok - 57 274; 1954 rok - 58 821; 1955 rok -8968$)^{53}$. Około 400000 woluminów oddała do Zbiornicy Surowców Wtórnych w Bytomiu. A na obszarze Polski, w byłych magazynach zbiornic, pozostawiła ponad 1000000 woluminów, które po selekcji w znacznej części przeznaczono na przemiał.

Na podstawie decyzji Ministerstwa Oświaty oraz Ministerstwa Kultury i Sztuki Zbiornica otrzymała 461 zezwoleń na wydanie dzieł przedstawicielom 270 bibliotek i instytucji z terenu Polski. Ogółem przekazała około 540000 woluminów książek, czasopism oraz innych materiałów bibliotecznych $^{54}$. W otrzymywaniu dzieł pierwszeństwo miały: Biblioteka Narodowa, Śląska Biblioteka Publiczna oraz Uniwersytet Wrocławski. W momencie likwidacji Zbiornicy, tj. 31 grudnia 1955 roku, w magazynach przechowywano 95815 woluminów ${ }^{55}$.

Reasumując, należy stwierdzić, że zabezpieczone zbiory w sposób znaczący przyczyniły się do odbudowy rodzimych bibliotek i polskiego bibliotekarstwa. Dzieła z krajowych zbiornic w pierwszej kolejności trafiały do bibliotek uniwersyteckich, Biblioteki Narodowej oraz innych instytucji naukowych. Według stanu z 31 grudnia 1949 roku księgozbiory zabezpieczone w bibliotekach uniwersyteckich oraz Bibliotece Narodowej liczyły ${ }^{56}$ :

- Biblioteka Jagiellońska - 550000 tomów,

- Biblioteka Katolickiego Uniwersytetu Lubelskiego w Lublinie - 57000 tomów,

- Biblioteka Uniwersytecka Marii Curie-Skłodowskiej w Lublinie - 123 534 tomy,

${ }^{52}$ F. Szymiczek, Akcja zabezpieczania bibliotek i księgozbiorów na Śląsku w świetle dokumentów i wspomnień własnych, „Książnica Śląska”, 1975-1978, t. 20, s. 50-51.

53 Tamże, s. 55.

${ }_{54}$ Tamże, s. 56.

55 Tamże, s. 57.

${ }^{56}$ AUWr, Statystyka zbiorów Biblioteki Uniwersyteckiej, sygn. BU 27, k. 36 - Zbiory i etaty personalne bibliotek uniwersyteckich i Biblioteki Narodowej. Stan na dzień 31 grudnia 1949 r. 
- Biblioteka Uniwersytecka w Łodzi - 238000 tomów,

- Biblioteka Uniwersytecka w Poznaniu - 350000 tomów,

- Biblioteka Uniwersytecka w Toruniu - 380000 tomów,

- Biblioteka Uniwersytecka w Warszawie - 210000 tomów,

- Biblioteka Uniwersytecka we Wrocławiu - 728651 tomów,

- Biblioteka Narodowa - 800000 tomów.

Ogółem dziewięć bibliotek naukowych posiadało aż 3437185 tomów pochodzących ze zbiorów zabezpieczonych ${ }^{57}$. Z tego za przydatnych dla bibliotek uznano w sumie 1632324 tomów.

Podjęta po raz pierwszy próba przedstawienia polskich zbiornic księgozbiorów zabezpieczonych, działających w latach 1947-1955, nie wyczerpuje tematu. Problemy związane $\mathrm{z}$ ich genezą, funkcjonowaniem oraz rezultatami pracy zostały zaledwie dotknięte. W kilkuletniej działalności placówek, niezwykle złożonej i skomplikowanej, występują podobieństwa, ale także różnice.

Należy stwierdzić, że w wyniku pracy siedmiu zbiornic (w Gdańsku, Katowicach, Krakowie, Poznaniu, Szczecinie, Toruniu oraz Wrocławiu) poddano ochronie oraz segregacji na terenie Polski kilka milionów tomów. Trafiły one przede wszystkim do uniwersytetów oraz licznych instytucji naukowych na terenie całego kraju. W sposób istotny przyspieszyły odbudowę rodzimych bibliotek po dotkliwych stratach okresu II wojny światowej. Wywarły znaczący wpływ na realizację postanowień pierwszej polskiej ustawy o bibliotekach i opiece nad zbiorami bibliotecznymi, z 17 kwietnia 1946 roku. Na podkreślenie zasługuje fakt, że od podstaw, z księgozbiorów zabezpieczonych, powstała Biblioteka Uniwersytecka w Toruniu. Uratowane liczne rękopisy, inkunabuły oraz stare druki pomogły odbudować i powiększyć krajowe zasoby zbiorów specjalnych. Pozwoliły również na powstanie działu zbiorów specjalnych, jak np. w Bibliotece Uniwersyteckiej w Poznaniu. Ocalone materiały stale służą rozwojowi polskiej nauki, a zwłaszcza bibliologii. Trzeba również pamiętać, iż znaczną liczbę tomów, uznaną za zbędną, przeznaczono na przemiał. Sytuacja ta wynikała nie tylko $\mathrm{z}$ dotkliwego braku pomieszczeń do magazynowania książek, zniszczenia fizycznego dzieł, przechowywania pozycji mających wartość makulatury (np. propagandy hitlerowskiej), ale także polityki państwa.

Ze względu na doniosłą rolę i znaczenie w odbudowie polskich bibliotek i rodzimego bibliotekarstwa problematyka zbiornic zasługuje na dalsze badania, które powinny doprowadzić do powstania monografii poświęconych

$57 \mathrm{Tj}$. poddanych ochronie od 1945 roku i przekazanych przez zbiornice w latach 1947-1949. 
poszczególnym instytucjom. Istnieje potrzeba podjęcia kompleksowych badań nad powojenną ochroną zbiorów bibliotecznych w Europie, dzięki którym będzie można dokonać częściowej weryfikacji dotychczasowych ustaleń dotyczących strat okresu II wojny światowej. W tym celu winno dojść do nawiązania współpracy i powstania międzynarodowych zespołów badawczych, prowadzących wielokierunkowe dociekania naukowe.

\section{DOKUMENTY ŹRÓDŁOWE}

\section{ARCHIWUM AKT NOWYCH}

Ministerstwo Oświaty. Naczelna Dyrekcja Bibliotek. Wydz.[iał] Bibliotek Naukowych. Zbiornica Księgozbiorów przy Bibliotece Uniwersyteckiej w Toruniu. Sprawozdanie z działalności za lata 1947-49, sygn. 6956.

Ministerstwo Oświaty. Naczelna Dyrekcja Bibliotek. Wydz.[iał] Bibliotek Naukowych. Zbiornica Księgozbiorów Zabezpieczonych w Gdańsku. Sprawozdania miesięczne z działalności za lata 1947-49, sygn. 6945.

Ministerstwo Oświaty. Naczelna Dyrekcja Bibliotek. Wydz.[iał] Bibliotek Naukowych. Zbiornica Księgozbiorów Zabezpieczonych w Gdańsku. Sprawozdania miesięczne z działalności za 1950 r., sygn. 6946.

Ministerstwo Oświaty. Naczelna Dyrekcja Bibliotek. Wydział Bibliotek Naukowych. Zbiornica Księgozbiorów Zabezpieczonych w Katowicach. Sprawozdania miesięczne z działalności za 1947 r., sygn. 6947.

Ministerstwo Oświaty. Naczelna Dyrekcja Bibliotek. Wydział Bibliotek Naukowych. Zbiornica Księgozbiorów Zabezpieczonych w Katowicach. Sprawozdania miesięczne z działalności za 1950 r., sygn. 6950.

Ministerstwo Oświaty. Naczelna Dyrekcja Bibliotek. Wydz.[iał] Bibliotek Naukowych. Zbiornica Ksiegozbiorów Zabezpieczonych w Krakowie. Sprawozdania z działalności 1948-1949, sygn. 6952.

Ministerstwo Oświaty. Naczelna Dyrekcja Bibliotek. Wydział Bibliotek Naukowych. Zbiornica Księgozbiorów Zabezpieczonych w Poznaniu. Sprawozdania $z$ działalności za lata 1945-1950, sygn. 6953.

Ministerstwo Oświaty. Naczelna Dyrekcja Bibliotek. Wydz.[iał] Bibliotek Naukowych. Zbiornica Księgozbiorów Zabezpieczonych w Szczecinie. Sprawozdanie z całokształtu akcji zabezpieczania księgozbiorów poniemieckich w latach 1947-50, sygn. 6955. 
Ministerstwo Oświaty. Naczelna Dyrekcja Bibliotek. Wydz.[iał] Bibliotek Naukowych. Zbiornica Księgozbiorów Zabezpieczonych we Wrocławiu. Sprawozdania miesięczne z działalności za 1948 r., sygn. 6958.

Ministerstwo Oświaty. Naczelna Dyrekcja Bibliotek. Wydz.[iał] Bibliotek Naukowych. Zbiornica Księgozbiorów Zabezpieczonych we Wrocławiu. Sprawozdania miesięczne z działalności za 1950 r., sygn. 6959.

\section{ARCHIWUM BIBLIOTEKI UNIWERSYTECKIEJ W POZNANIU}

Referat zabezpieczania i segregacji zbiorów. Zarządzenia, instrukcje i upoważnienia 1944-1946, sygn. 535.

\section{ARCHIWUM UNIWERSYTETU WROCŁAWSKIEGO}

Przekazanie Biblioteki Miejskiej Uniwersytetowi, sygn. BU 82.

Statystyka zbiorów Biblioteki Uniwersyteckiej, sygn. BU 27.

\section{Abstract \\ Polish Warehousing Centres for Protected Book Collections between 1947 and 1955}

This paper presents the origins, activities and results of the work of seven Polish Warehousing Centres for Protected Book Collections. They were established by the decision of the Ministry of Education on February 1, 1947, in Gdansk, Katowice, Krakow, Poznan, Szczecin, Torun and Wroclaw. The longest operating one, until December 31, 1955, was the Warehousing Centre for Protected Book Collections in Katowice.

It should be noted that due to the work of the Warehousing Centres on the Polish territory, several million volumes, mostly of former German provenance, underwent protection and segregation.

They were given primarily to universities and numerous academic institutions across the whole country. This significantly accelerated the restoration, after severe losses of the World War II period, of domestic libraries and Library Science. The saved works continuously aid the development of Polish science, especially Library Studies. 
The issue of Warehousing Centres is worthy of further research. There is a need for undertaking comprehensive studies of post-war protection of library collections in Europe, so that a partial reassessment of existing findings regarding the losses suffered during the World War II period would be possible. Thus, an international cooperation and the formation of teams leading multi-scientific inquiries should be established.

Translated by Marta Nowicka 